\title{
International Criminal Law and the Inner Morality of Law
}

Follow this and additional works at: http:/ / digitalcommons.osgoode.yorku.ca/ transnationalism_series

\section{Recommended Citation}

"International Criminal Law and the Inner Morality of Law" (2009). Legal Philosophy between State and Transnationalism Seminar Series. 32.

http://digitalcommons.osgoode.yorku.ca/transnationalism_series/32 
International Criminal Law and the Inner Morality of Law

Larry May

W. Alton Jones Professor of Philosophy and Professor Law Vanderbilt University and Strategic Research Professor of Social Justice, Centre for Applied Philosophy and Public Ethics (CSU) in Canberra

In Book V of the Nicomachean Ethics, Aristotle gives one of the first statements of the rule of law when he says: "we allow only reason, not a human being, to be ruler."1 Aristotle then divides political justice into two parts. "One part of the politically just is natural, and the other part legal. The natural has the same validity everywhere alike, independent of its seeming so or not.” ${ }^{2}$ This characterization of the natural part of justice is sometimes associated with the so-called natural duties of justice, specifically with the substantive duties to promote just institutions. But, it seems that Aristotle, at least at that point in his Ethics, is referring to something procedural, what might be called 'natural fairness.'

In my view, the debate between Hart and Fuller about the internal aspect of rules or the inner morality of law concerns an issue that is similar to what Aristotle meant by the natural part of justice, namely that part of natural fairness that stays the same from society to society, and perhaps even outside of particular societies - for instance, in the international arena. In this respect one could ask whether there is something like a natural duty to support procedures, such as habeas corpus, that provide minimal fairness for those who have been incarcerated or detained. And if there is such a duty, is it part of the inner morality of law? In his eighth desiderata of the rule of law, Fuller mentions such

\footnotetext{
${ }^{1}$ Aristotle, Nicomachean Ethics, $1134 \mathrm{a} 35$.

2 Ibid., 1134 b20.
} 
things as habeas corpus as an aspect of procedural due process, but he does little more than mention it; Hart does not mention it at all. But both legal theorists are focused as much on procedural as substantive justice.

In what follows I will investigate what Fuller called "procedural natural law" in contemporary international criminal law. Most of the theoretical and normative writings about international criminal law have so far been about substantive law, focusing on the four crimes over which the International Criminal Court has jurisdiction: crimes against humanity, war crimes, genocide, and the crime of aggression. ${ }^{3}$ International justice is thought to have come to maturity as these four substantive crimes have been prosecuted by international tribunals and courts. In my view, it is time for international legal theorists and practitioners to take into account procedural issues in as much detail as has been given to substantive ones. I will argue that procedural rights are part of what constitutes the rule of law and are especially important as gap fillers in creating an international rule of law that respects fundamental fairness. International criminal law will not come to maturity as a system of law unless protections of fundamental fairness, such as a global right of habeas corpus, are put in place.

In this paper I will use the Hart/Fuller debate as a springboard for assessing procedural rights within the context of the international rule of law. In the first two sections I will rehearse the relevant part of the Hart/Fuller debate as it pertains to the subject of international law and also to the inner morality of law. In the third section I will set out some of my views on these matters, drawing on both Hart and Fuller,

\footnotetext{
${ }^{3}$ I have written studies of each of these substantive international crimes: Crimes Against Humanity: A Normative Account (Cambridge University Press, 2005); War Crimes and Just War (Cambridge University Press, 2007); Aggression and Crimes Against Peace (Cambridge University Press, 2008); and Genocide: A Normative Account, (Cambridge University Press, forthcoming in 2009).
} 
concerning the value of fundamental procedural rights. In the fourth section I will discuss the right of habeas corpus, as a good test case of how to think about these issues. In the final sections I will expand on these remarks and argue that procedural rights need to be better protected in international law, if it is to have a claim to legitimacy as a mature legal system.

\section{Hart on International Law and the Rule of Law}

H.L.A. Hart draws a distinction between primary rules, in which "human beings are required to do or abstain from certain actions,” and secondary rules, which may introduce, extinguish, or modify primary rules. ${ }^{4}$ Hart is often interpreted as requiring a rule of recognition, which involves secondary rules that establish how primary rules are to be recognized as valid law; indeed Ronald Dworkin talks about the rule of recognition as a "master rule" for Hart. ${ }^{5}$ Yet, in Hart's treatment of international law in the final chapter of his book, The Concept of Law, he does not deny that international law is law, even though international law, at least in the early 1960s, seemed to Hart to lack a rule of recognition. In this respect, consider the final sentence of his book:

Bentham, the inventor of the expression 'international law,' defended it simply by saying that it was 'sufficiently analogous' to municipal law. To this two comments are perhaps worth adding. First, that the analogy is one of content not of form; secondly, that in the analogy of content, no other social rules are so close to municipal law as those of international law. ${ }^{6}$

\footnotetext{
${ }^{4}$ H.L.A. Hart, The Concept of Law, Oxford: Oxford University Press, 1961, 1994, p. 81.

${ }^{5}$ For example see Ronald Dworkin, “The Model of Rules I,” Taking Rights Seriously, London: Duckworth, 1977, p. 41.

${ }^{6}$ Ibid., p. 237.
} 
This is not to say that formal features of a system of rules were unimportant to Hart. But on the penultimate page of his book, Hart spoke of emancipating "ourselves from the assumption that international law must contain a basic rule." ${ }^{7}$

Hart himself often says that law is best understood as the "union of primary and secondary rules.” But by the last chapter of his book, the chapter on international law, Hart is at pains to point out that while this union provides a "sufficient condition for the application of the expression 'legal system'” he has not claimed "that the word 'law' must be defined in its terms.” Instead, he says that the "idea of a union of primary and secondary rules...may be regarded as a mean between juristic extremes.”8 Arguably, what is even more important for Hart for establishing that a set of rules is a legal system is whether the people who live under the set of rules have an internal perspective or point of view toward these rules, where one is concerned with rules "as a member of a group which accepts and uses them as guides to conduct."

For Hart, the internal perspective is crucial for legal systems, but there are arguably two candidates for this perspective, only one of which is truly so. What is crucial for distinguishing "social rules from mere group habits" "is that there should be a critical reflective attitude to certain patterns of behavior as a common standard, and that this should display itself in criticism (including self-criticism), demands for conformity, and in acknowledgement that such criticism and demands are justified...”10 Taking this internal perspective is crucial for the proper functioning of a system of rules that is considered authoritative and deserving of obedience.

\footnotetext{
${ }^{7}$ Ibid., p. 236.

${ }^{8}$ Ibid., p. 212.

${ }^{9}$ Ibid., p. 89.

${ }^{10}$ Ibid., p. 57.
} 
In Hart's view, international law can be law properly so-called. In the early 1960s Hart already recognized that international law very closely resembled domestic municipal law in its content, although not in its form, since international law lacked a rule of recognition. Indeed, Hart probably would say something different today, especially with the institution of the International Criminal Court and its complex statute, as well as with the growing recognition and acceptance of the legitimacy of international law in nearly all quarters. But there is another way to understand the legitimacy of the claim that international law is law properly so called.

International law is easier to understand if one focuses on such things as "the internal aspect of rules” rather than sovereignty which creates or enforces a master rule. As Hart recognized, there is an "absence of an international legislature, courts with compulsory jurisdiction, and centrally organized sanctions.” These absences have inspired “misgivings” about whether international law is properly called law, especially since the absence of such things seems to indicate a lack of a rule of recognition. ${ }^{11}$ Hart was seemingly not one of the people who had these misgivings, at least not in a way that made him doubt that international law could be law properly so called. The fact that Hart recognized that many saw international law as a "doubtful case," 12 and that he placed international law in his last chapter, indicates that he also saw it as a hard case. But as I have been arguing, he probably also saw international law as a good example for discussing the relative importance of the internal point of view as opposed to the union of primary and secondary rules in identifying when there is a system of law.

\footnotetext{
${ }^{11}$ Ibid., p. 214.

${ }^{12}$ Ibid., p. 3.
} 
In eventually taking up the case of procedural rights like habeas corpus it will be important to remember that Hart stressed the importance of "demands for conformity" with primary rules, as well as a "centrally organized system of sanctions.” In international law, especially international criminal law, both of these factors are currently hard to satisfy in a rigorous way since there is no sovereign international state that can accomplish or facilitate these things. But gaps in sanctions can be filled without a fully centralized system in place, especially if the relevant officials take an internal perspective toward the law. Especially in high profile cases, indictment and arrest procedures that are piecemeal can go a long ways, as can other piecemeal ways to protect substantive rights internationally.

At the end of the paper, I will take up the case of the Guantanamo detainees who tried to get their substantive rights protected even though there was no centrally organized international sanctioning power. The Guantanamo detainees filed habeas corpus petitions in order to put public pressure on the United States government to protect their substantive rights. And in addition, habeas corpus appeals sought to prevent the "legal black holes" that had seemingly opened because of a lack of a gapless international legal system. In this sense, habeas corpus was a gap-filler that helped establish an international rule of law even though there are still not executive and legislative branches of an international government.

As international law comes to have more institutional arrangements that are like municipal law, Hart was right to think that it will resemble municipal law in form as well as in content. And we are certainly moving in this direction with the creation of the International Criminal Court with some compulsory jurisdiction and centrally organized 
sanctions, at least for those States that have ratified the Rome Treaty. And as the Security Council acts more and more like a world legislature, similarly international law moves closer to municipal law. There is still a lack of fully centralized sanctions in international law, although the various appellate courts at the ICTY, ICTR, and ICC have been striving valiantly to create a piecemeal uniformity of sanctions, despite lacking a fully centralized mechanism of enforcement of its indictments and judgments. But in the mean time, what has been most striking since the early 1960s, when Hart wrote his book, is how far the world community has moved in developing an internal perspective on international law, especially international criminal law. And with the development of this perspective, some of Hart's worries about international law have been addressed.

In chapter 9 of The Concept of Law, Hart launches his own positive discussion of natural law by explaining that there is a "rational connection between natural facts and the content of legal and moral rules." Without a minimal natural content to the law, “men, as they are, would have no reason for obeying voluntarily any rules.” 13 At least some members of the society must voluntarily accept the rules. "Without their voluntary cooperation, thus creating authority, the coercive power of law and government cannot be established"14 And for the system to be most stable, these people "must conceive of themselves as morally bound to do so.”15 The natural facts must be satisfied for such an acceptance, and their acceptance is expressed in "internal statements" but this does not mean that they "are thereby committed to a moral judgment."16

\footnotetext{
${ }^{13}$ Ibid., p. 93.

${ }^{14}$ Ibid., p. 201.

${ }^{15}$ Ibid., p. 203

${ }^{16}$ Ibid.
} 
So for Hart there is a relationship between the minimal content of natural law and the internal perspective; but what is unclear is exactly what the relationship is. And more importantly for my paper, why restrict the relevant natural facts to the content of rules instead of also to the minimal form of these rules. Would Hart recognize the kind of procedural natural law that Fuller discussed, and that Aristotle seemed also to embrace. Hart seems to suggest that the form also matters, when he addresses Fuller directly by claiming that "in general [rules] must not be retrospective, though exceptionally they may be.”17 Hart even allows that such considerations may properly be called "the inner morality of law” yet he couches this acceptance of Lon Fuller's terminology by then stipulating "It is unfortunately compatible with very great iniquity." 18

Some content and also some form seems to be required for law to attain the voluntary acceptance of some of the population. Hart has put his finger on a crucial point - certain things are required for any system of rules to attain sufficient voluntary acceptance in a population to be called a system of law. And Hart's own emphasis on secondary rules as involving largely procedural matters points us toward what must be better secured in international law if there is to be a system of law in the international domain that achieves acceptance as well. Or at least this is one way to interpret Hart's claim that international law resembles municipal law in content but not yet in form. When international law acquires municipal law's form it will then have a claim to be a mature system of law. As I will indicate in the ensuing discussion of Fuller, the form that is most important is that there is a guarantee of formal fairness that largely comes from the protection of procedural rights.

\footnotetext{
${ }^{17}$ Ibid.

${ }^{18}$ Ibid., p. 207.
} 


\section{Fuller on Procedural Natural Law}

Lon Fuller was critical of many of the theses and arguments advanced by Hart, but there is nonetheless a striking similarity in how they regarded the internal perspective of a system of law. Hart does recognize the connection between this internal perspective and what he called the minimal content of the natural law, and Fuller makes this connection more explicit and in that sense moves us forward in understanding what needs to happen for international law to become a mature system of law. Whether or not Fuller really does fit into the natural law tradition, he does link something like Hart's internal perspective to certain minimal natural law, and what he also calls moral, considerations that have historically been identified with the rule of law.

For Fuller, there are eight desiderata that when not satisfied lead to disaster for the rule of law. Here are the ways failure can occur:

(1) a failure to have rules at all;

(2) a failure to publicize...the rules;

(3) the abuse of retroactive legislation;

(4) a failure to make rules understandable;

(5) the enactment of contradictory rules;

(6) rules that require conduct beyond the powers of the affected party;

(7) introducing such frequent changes in the rules that the subject cannot orient his action by them;

(8) a failure of congruence between the rules as announced and their actual administration. $^{19}$

\footnotetext{
${ }^{19}$ Lon Fuller, The Morality of Law, New Haven, CT: Yale University Press, 1964, 1969, pp. 39 and 96.
} 
And Fuller helps us understand what is necessary for a set of rules to be a legal system when he says that his eight desiderata concern

a procedural, as distinguished from a substantive, natural law. What I have called the internal morality of law is in this sense a procedural version of natural law, though to avoid misunderstanding the word 'procedural' should be assigned a special and expanded sense so that it would include, for example, a substantive accord between official action and enacted law. ${ }^{20}$

For Fuller, "substantive natural law" concerns "the proper ends to be sought through legal rules. ${ }^{21}$ Procedural natural law is necessary for rules to be rules at all, and for them to form a system. In this respect there appears to be a connection between the internal perspective on rules that Hart identified and Fuller's inner morality of law.

The inner morality of law is a set of procedures, such as non-retroactivity, that rules must conform to in order for there to be a system of rules at all. As Hart pointed out, to call this an inner "morality" is questionable, especially since it is compatible with great iniquity. Fuller contends that a system of rules that satisfied his eight desiderata would not be a system that could be gravely iniquitous. Whether properly moral or not, there is no doubt that these desiderata are procedural constraints on rules that when adhered to make of these rules a system of rules that is deserving of respect. And in that sense they satisfy Hart's concern that law appeal at least to some members of society as fair and just and hence deserving of their voluntary cooperation and recognition as being authoritative. One way to begin to understand the possibility of common ground between Hart and

\footnotetext{
${ }^{20}$ Ibid., pp. 96-97.

${ }^{21}$ Ibid., p. 98.
} 
Fuller is to see that the inner morality of law must be satisfied in order for people within the system of rules to take an internal perspective toward these rules.

In my view, Hart and Fuller did not really disagree much about what constitutes the inner morality of law. Rather they disagreed about whether and to what extent it really was a 'morality' that connected to ideas such as justice and fairness in a way that blocks iniquity within a system of law. In another place I have suggested that this was at best a minimal moral notion, but that is not to denigrate its moral character nonetheless. ${ }^{22}$ Perhaps this is merely to say that these requirements must be satisfied for a system of law to deserve our fidelity to it, where this might capture what both Hart and Fuller wanted, although they both failed to recognize an important aspect of these procedures.

For Fuller, concerning any legal system the procedural natural law can be summarized in one expression, "due process of law." ${ }^{23}$ Fuller gives as an example "judicial review." ${ }^{24}$ And he says "What law must foreseeably do to achieve its aims, is something quite different from law itself., ${ }^{25}$ But why does Fuller think that certain procedural matters are not properly part of the legal system, rather than merely being different types of procedure within a system of law? Perhaps some procedures directly protect substantive rights and others do so in a less direct, although no less important way. Indeed that is what he says of the eighth desiderata. There may be due process rights that guarantee that legal systems have a substantive fairness. But also there may be other procedural matters that protect the formal fairness of a system of law without having much to do with any particular substantive right.

\footnotetext{
${ }^{22}$ See my treatment of this topic in the first few chapters of my book, Crimes Against Humanity: A Normative Account (Cambridge UP, 2005).

${ }^{23}$ Fuller, ibid., p. 103.

${ }^{24}$ Ibid., p. 104.

${ }^{25}$ Ibid., p. 108.
} 
Fuller says, "It is precisely when the legal system takes up weapons of violence that we impose on it the most stringent requirements of due process.” Fuller then says that whenever people embark on "subjecting certain kinds of human conduct to the explicit control of rules" "they come to see that this enterprise contains a certain inner logic of its own, that it imposes demands that must be met (sometimes with considerable inconvenience) if its objectives are to be attained. ${ }^{26}$ But Fuller did not seem to see that some rules, like those of habeas corpus, could be very important and yet not necessarily protect any substantive rights. Indeed, habeas corpus is just the kind of procedural right that would protect formal as opposed to substantive fairness of a system of law, since what habeas corpus primarily protects against is arbitrariness of decisions.

For Fuller, following his eight desiderata would require that there be stringent rules of due process for there to be international criminal law. And this includes judicial review, something currently lacking. As I will argue later, I believe that one of the best things to do to begin to bridge this gap is for there to be an institutionalized international version of procedural natural law including a right of habeas corpus. In criminal matters, habeas corpus functions as a rudimentary basis of something like judicial review. Interestingly, Fuller does mention habeas corpus once in The Morality of Law, and links it to "procedural due process" under his eighth desiderata, the "Congruence Between Official Action and Declared Rule."27 And he did recognize that it is in this eighth desiderata that there would be rules that were not necessarily themselves part of the legal system. But he didn't put these pieces together and hence missed an important point for law in general and international law in particular.

\footnotetext{
${ }^{26}$ Ibid., pp. 150-151.

${ }^{27}$ Ibid., p. 81.
} 


\section{Valuing Visibleness and the Rule of Law}

In considering the idea of formal or procedural natural law, one wonders whether Hart would recognize a "minimal form of the natural law" similar to the "minimal content of the natural law.” Would Hart regard certain procedural matters, such the right to habeas corpus, as similar to the substantive prohibitions on murder or theft, as key components for any legal system, given what we know of humans? While neither Hart nor Fuller addressed this issue directly, I believe that key components of the rule of law would indeed be seen by both theorists as important for the natural justice of a legal system. In what follows, I am sympathetic to Fuller's brief suggestion that a version of procedural natural law involves a right of habeas corpus, among other basic due process rights. In criminal matters, habeas corpus functions as a rudimentary basis of something like judicial review.

The value of habeas corpus concerns what I call the normative principle of visibleness $^{28}$ in detention and incarceration as a counter to the secrecy that masks arbitrary exercise of power in this domain. Habeas corpus stands for the proposition at its most minimal, but also at its most powerful, that no one can be hidden in jail or prison. And the reason for this is that such secrecy is too likely to hide mistreatment and abuse. Henry Maine said that "substantive law has at first the look of being gradually secreted in the interstices of procedure." 29 It is fitting that what is secreted in the interstices of the procedural right of habeas corpus is the moral principle against secrecy in confinement. Habeas corpus is in one respect the idea that the body of the prisoner must literally be made publicly visible, but this very rudimentary procedure has very great value.

\footnotetext{
${ }^{28}$ The OED lists, as one of the earliest uses of the term visibleness, a $16^{\text {th }}$ century reference to the fact that the Catholic Church did not maintain open procedures.

${ }^{29}$ Sir Henry Maine, Dissertations on Early Law and Custom, NY: Henry Holt and Company, 1886, p. 389.
} 
For several thousand years, philosophers have embraced the idea that if one were invisible the normal moral constraints would not be operative. This is presumably as true of Plato’s Lydian shepherd who could make himself invisible and hence avoid detection of his crimes, as of the jailer who can make the prisoner invisible and hence hide the jailer's crimes as well. Arbitrariness often seems to need the cloak of secrecy and invisibility. The Lydian shepherd may use his new power for the good of his people, but if he then chooses to use if for ill, there is no stopping him from doing so. The ruler, or jailer, who discovers that he can render a person invisible from public view, may also use this power for wrongdoing, or for hiding wrongdoing, and such abuse of power is at least partially stopped by the anticipation of habeas corpus appeals.

The principle of visibleness does not guarantee that those who are detained or incarcerated will not be treated wrongly or even that they will be treated fairly, but only that if they are to be treated unfairly it cannot be done completely in secret. Blackstone, writing in the $18^{\text {th }}$ century, put this point quite well:

But confinement of the person, by secretly hurrying him to gaol, where his sufferings are unknown and forgotten; is a less public, a less striking, and therefore a more dangerous engine of arbitrary government. ${ }^{30}$

Security of the person is often a key by-product of habeas corpus. The principle of visibleness is a protection of personal security, which, as Justice Kennedy said, "subsists, too, in fidelity to freedom's first principles.”31

The prospect of the revelation of the wrongdoing through even a very rudimentary habeas corpus procedure may act as a deterrent against the wrongdoing occurring at all,

\footnotetext{
${ }^{30}$ William Blackstone, Commentaries on the Laws of England (1765), facsimile of the first edition, Chicago: University of Chicago Press, 1979, Volume 1, p. 132.

${ }^{31}$ Boumediene v. Bush, 553 U.S. __ (2008), p. 68.
} 
or against similar wrongdoings occurring in the future. And in this sense habeas corpus is clearly related to a human good, namely that wrongdoing should not occur. But habeas corpus is not directly related to this good, but indirectly so. And it is my view that this is the way that procedural rights are normally related to substantive ones. Procedural rights do not normally have value in themselves, but only as they somehow support substantive rights. There is one exception to this idea and that concerns the so-called rule of law.

Merely having some procedural rules that govern human affairs is often thought to be of value insofar as rule by these rules is better than rule by "man." In this sense rule by rules is definitive of the rule of law and against the kind of arbitrariness that comes when people make decisions unconstrained by rules. Procedural rules have value here because they are constitutive of a norm, not merely because they support some other norm. The norm that these procedural rules constitute is itself a procedure. Procedural rights can have intrinsic value in that they are constitutive of a rule of law which promotes fairness. In this sense, procedural rights do not necessarily have content and while they aim at a certain good, that good, fairness and non-arbitrariness, need not have content, unlike the goods that substantive rights aim at such as property rights or free speech rights which have content and aim at a human good.

Non-arbitrariness is related to a type of fairness that involves complying with a rule joined with a system of overseeing that the rule is complied with. Political orders are arbitrary both by having rule by the whim of a person or persons, instead of by a rule, and by having no oversight. The value of non-arbitrariness is hard to characterize. There is a kind of formal fairness that is achieved when procedural rights are respected. Habeas corpus provides a minimal rule for how jailers and rulers should behave, and also a 
rudimentary system for oversight. In this sense habeas corpus epitomizes procedural fairness. Of course, there is also value to procedural rights in the various ways that they are means to substantive ends.

Habeas corpus was initially thought of as merely the right to be brought from the dungeon and told of the charges against one. At nearly the same time, the right also came to be seen as a right to have those charges assessed to see if there was a prima facie reason to think that they had any basis, and this was understood as the right not to be arbitrarily incarcerated. Later, habeas corpus came to stand for the right to due process in general. And later still habeas corpus was understood, as it is today in the American system of law, as a right to challenge an incarceration on the basis of any of one's significant constitutional liberties. So, the history of habeas corpus incorporates at least three different ways to understand this right. In the first instance, habeas corpus is a nonderivative procedural right since the right to be brought into the light of day and told of the charges against one does not address the substantive charges or the eventual trial of the accused. In the second instance, the right becomes a derivative procedural right, especially when it is seen as protecting certain substantive rights such as the right against arbitrary denial of liberty. Finally, habeas corpus comes to be seen as a substantive right, to particular constitutional liberties.

Habeas corpus can be constitutive of the rule of law in that it is clearly better that prisoners be treated according to a regime that has the habeas corpus rule than subject to the possibly arbitrary rule of their jailers. Habeas corpus is a paradigmatic constituent of the rule of law insofar as it stands against the arbitrary exercise of authority. Generally, the rule of law concerns the limitation on a ruler's authority by rules imposed on rulers, 
not made by them. The value of the rule of law, as with the value of habeas corpus which is itself part of the rule of law, is not merely in the substantive values it advances but also, in a curious way, in the value that inheres in a system of rules that restricts, or places "stops" in the way of, arbitrariness. Arbitrariness is a disvalue in itself that is not necessarily connected to a specific human good, at least not in a direct way.

Concerning rights like habeas corpus, Larry Alexander has argued that these procedural rights have value only as that value derives from the substantive right "to liberty from confinement." ${ }^{\text {’2 }}$ I do not deny that sometimes this is true of procedural rights like habeas corpus. But I think that the more important and more interesting value of habeas corpus has to do with its intrinsic value as part of the rule of law. And here what is important is protecting people against arbitrariness that may not support any other substantive right. It may be that the liberty from confinement is unaffected by habeas corpus rights since the prisoner gains only very temporary removal from confinement associated with this right, as I have indicated above. Alexander may be right that there is a worry about certain risks, but specifying what the risk is in the case of a denial of habeas rights is not always easy to do. And it is sometimes unclear what substantive right is risked when the rule of law is denied. I follow Fuller in thinking that a version of procedural natural law involves a rudimentary right of habeas corpus, among other basic procedural rights, and that such rights form the basis for at least a minimal moral fairness in a system of law.

\section{Fundamental Procedural Rights}

\footnotetext{
${ }^{32}$ Larry Alexander, “Are Procedural Rights Derivative Substantive Rights?” Law and Philosophy, vol. 17, no. 1, January 1998, p. 31.
} 
When there is no Constitution, fundamental law typically refers to certain longstanding customs, perhaps even being "fixed and unalterable."33 The customs themselves may articulate principles, but they are not the same as the principles, and certainly do not gain their authoritativeness merely from being long-standing. ${ }^{34}$ The principles are moral principles that derive their authority in the way all moral principles do, because of their claim to legitimacy. Typically there are a small set of substantive principles that are thought to be definitive of a particular political society, such as freedom of speech, press, and association, or nondiscrimination on the basis of race or gender. Like the principles that undergird a Constitution, in a society without a Constitution there are principles that also provide a foundation for the political and legal system.

"Fundamental law" is a phrase that came to have its most important meaning in $17^{\text {th }}$ Century England. Habeas corpus is not itself fundamental law in the sense of being a body of substantive principles undergirding a legal system, but habeas corpus can be significantly intertwined with fundamental law. Procedural, not merely substantive, rights are significant in fundamental law because of the two important roles procedural rights play. As we saw above, some procedural rights are instrumentally valuable as they complement substantive rights. One way that they can do this is by gap-filling. Again following Aristotle, equity relies on such gap filling insofar as the substantive rules of any system of rules will not always fit the specific case in the way the drafters of the rules envisioned. In particular, habeas corpus can be a gap-filler in that its requirement of visibleness may inhibit kings and presidents from finding loop-holes by which prisoners can be abused, or where other forms of unfairness can creep into the system of law.

\footnotetext{
${ }^{33}$ Gough., p. 15.

${ }^{34}$ See my discussion of the problems with custom in my book Crimes Against Humanity.
} 
Habeas corpus minimally involves a deceptively simple procedure, namely, that a person must be brought out of the dungeon and have the charges against him or her publicly recited. This procedure is a bulwark against some of the most serious forms of oppression. Individuals are more secure because governments are deterred from incarcerating indefinitely, or threatening to do so, those who exercise their substantive rights to speech, press, or assembly. The procedural right of habeas corpus helps secure these substantive rights. Indeed, whatever the substantive rights are, habeas corpus will help secure them. Whatever the substantive rights, habeas corpus appeals make sure that there is a minimum of protection in a system of law that has those substantive rights at its core.

As fundamental law, procedural rights like habeas corpus are also valued intrinsically in that they support basic fairness within the legal system. Such rights do not specify any right to a particular form of treatment or liberty that the State must protect. Rather these rights are what minimally must be done so that arbitrariness does not creep into the way that people are deprived of their liberty by being incarcerated. And minimal procedural fairness translates into the embodiment of the moral fairness that is necessary for a system of law to be deserving of fidelity on the part of the population at large. When there is arbitrariness in the system of law the rule of law is disrupted and the system of law becomes fundamentally undermined. In this respect, Fuller was on the right track, although he seemed somewhat unsure where to place habeas corpus rights within his schema of procedural natural law.

While it may be that substantive rights undergo change over time, having procedural rights remain constant is crucial, especially since there is much less need for 
procedural rights to change over time. Habeas corpus is of this sort - a procedural right that can remain fixed even as the particular substantive crimes that could lead to arrest and incarceration might vary over time. Basic moral fairness is achieved in the system of law when there is such a fixed set of procedural guarantees as that provided by habeas corpus. Here habeas corpus that guarantees that no prisoner is locked away for arbitrary reasons, or as a way to deny other important moral rights of the prisoner, helps secure a foundational moral minimum.

Both Hart and Fuller recognized the importance of procedural considerations to the rule of law. Hart saw these procedures as secondary rules and Fuller saw them as desiderata for the rule of law. Arguably, both theorists saw these procedures as a minimal moral core, although Hart continued to downplay the sense of morality here. In taking as my point of departure this part of the Hart/Fuller debate what I have stressed, though, is the point of seeming agreement between them that if there is to be a system of criminal law (whether domestic or international), not merely a set of laws, then attention needs to be placed on procedural not merely substantive rights.

The Hart/Fuller debate highlights the importance of procedural rights and also raises the question of whether there is a sense that fundamental fairness requires certain procedures, placing limits on constructivist approaches to procedural justice. Whether we call the fundamental rights properly moral or not, certain procedural rights must be contained as secondary rules if there is to be a fair system of law. As I will next claim, in international law in general, and international criminal law in particular, attention needs to be placed as much on procedural or secondary rules and tights as on primary or substantive rules and rights. And there is a very practical benefit to this attention. 
Looking to the global right of habeas corpus provides a way to fill gaps and prevent legal black holes such as existed at Guantanamo Bay.

\section{Habeas Corpus and International Law}

Several recent international criminal decisions have addressed habeas corpus rights, but only in the context of specific proceedings already begun at The Hague, not in a broader context that would apply habeas to cases like that at Guantanamo Bay where a gap existed in the system of international law. In the Kanyabashi case, the International Criminal Tribunal for Rwanda (ICTR), recognized the international right of habeas corpus, but confined it to "a review of the legality of detention" of those accused who are currently held by the ICTR. ${ }^{35}$ In this way, habeas corpus is restricted in two significant respects. First, there is an attempt to restrict the scope of habeas proceedings so that it only concerns the prima facie legality of the arrest and incarceration, not allowing habeas corpus petitions to be granted where there is a prima facie case for the conviction of the person incarcerated. Secondly, habeas is restricted only to arrest and detention of those who are currently held by international tribunals and courts. I take up the first issue in the current section and the second issue in the next section.

Two very important things come out of the ICTR decisions in the early part of the first decade in the $21^{\text {st }}$ century. First, the right of habeas corpus was there recognized as a fundamental, or jus cogens, right. This in effect gives habeas corpus the status of fundamental international law. But second, this right was greatly limited - making it a much more restricted procedural right than is true in Anglo-American Common Law.

\footnotetext{
${ }^{35}$ Prosecutor v. Kanyabashi, International Criminal Tribunal for Rwanda, Trial Chamber II, Case No. ICTR-96-15-I, May 23, 2000, Decision of the Defence Extremely Urgent Motion on Habeas Corpus and for Stoppage of the Proceedings, para. 28.
} 
Indeed, in the Barayagwiza case, the ICTR Appeals Chamber ultimately reversed the dismissal of the charges against Barayagwiza with prejudice, reinstating the case, despite the seemingly egregious violations of habeas corpus.

For my purposes, one of the most important findings of the string of cases at the ICTR is that habeas corpus is a fundamental right of international humanitarian law. It is not surprising that there was such a ruling, given that the International Covenant of Civil and Political Rights had listed the right against arbitrary arrest. But it is one thing to have the substantive right against arbitrary arrest recognized, and quite another matter to have a specific procedure, like habeas corpus, protected as a fundamental right as well. There is in my view a significant difference between the recognition that people have a substantive right not to be arbitrarily incarcerated, and the procedural right to what is necessary to enforce the substantive right through a review to determine if one has been arbitrarily incarcerated. In the case of habeas corpus there is also a non-instrumental reason to elevate it to jus cogens status as well.

Christian Tomuschat, a very well respected international legal theorist talks of jus cogens norms, the most fundamental norms of international law, as "rules of conduct which proscribe certain attacks on a number of particularly cherished goods of the international community.”36 Democracy and the rule of law are goods, even if not the sort of goods that are typically listed as important human goods, such as health and wellbeing. Rather than goods of bodily integrity, for instance, the rule of law is a good of fairness. Indeed, fairness is cherished by the international community as is true of all

\footnotetext{
${ }^{36}$ Christian Tomuschat, “Concluding Remarks,” in The Fundamental Rules of the International Legal Order: Jus Cogens and Obligations Erga Omnes, edited by Christian Tomuschat and Jean-Marc Thouvenin, Leiden: Martinus Nijhof, 2006, p. 430.
} 
communities. Insofar as it is an important good, the rule of law should be promoted as should those things that are constitutive of it, such as habeas corpus.

One author has summarized the state of procedural rights in terms of the idea of internationally recognized jus cogens norms as follows:

in addition to the substantive rights expressly declared to be non-derogable, a number of procedural rights which are instrumental to the effective protection of non-derogable rights, must also be respected in all circumstances. Among them is the right to have access to the domestic courts for violations of non-derogable rights, and the right of habeas corpus. Some fundamental aspects of the right to fair trial are also generally considered as non-derogable. ${ }^{37}$

I would only add that some procedural rights, such as habeas corpus, should be seen as jus cogens even if not strongly instrumental in this way. The intrinsic value of habeas corpus also needs to be recognized.

If there is to be an international rule of law certain core rights will have to be protected against abuse wherever in the world that abuse occurs. And a good example is the failure of the United States government to provide core procedural rights at the prison in Guantanamo Bay, Cuba. It seemed as if there was a legal black hole, and indeed that was just what certain members of George Bush’s administration actually advocated. If human rights are to be protected globally, and if there is to be a system of international criminal law, protecting such procedural rights as habeas corpus across the world is crucial.

\footnotetext{
${ }^{37}$ Silvia Borelli, "Casting Light on the Legal Black Hole: International Law and Detentions Abroad in the “War on Terror," International Review of the Red Cross, vol. 87, no. 857, March 2005, (pp. 39-86), p. 55.
} 


\section{Habeas Corpus and Guantanamo Bay}

I wish to conclude by offering a set of reasons to think that habeas corpus should be protected by international legal institutions in a much less restricted way than international criminal law (ICL) case law has so far recognized. I will turn now to the much more controversial and much richer global habeas right that would apply to all accused, not just those held at The Hague or in Arusha, to have their cases reviewed by the ICC or some comparable international court that has compulsory jurisdiction. I will begin by briefly rehearsing some of the facts of the Guantanamo case that has motivated my study.

After September 11, 2001, the United States and its allies arrested hundreds of supposed enemies of the United States in Afghanistan. Starting in January of 2002, many of those arrested were transferred to a prison at Guantanamo Bay. The detainees were held in captivity without access to legal counsel and without even having their names released or the charges against them publicly proclaimed. One administration official said that the principal motivation for transfer to Guantanamo was that it was "the legal equivalent of outer space.” And a British judge referred to Guantanamo detainees as existing in a US created "legal black hole."38

In 2002 the Inter-American Commission on Human Rights (IACHR) considered a petition from some of the detainees at Guantanamo who argued that their habeas corpus rights had been violated. On March 22 of that year the Commission issued “precautionary measures in favor of the detainees being held by the United States at Guantanamo Bay, Cuba.” The Commission “decided to request that the United States

\footnotetext{
${ }^{38}$ Sylvia Borelli, "Casting Light on the Legal Black Hole: International Law and Detentions Abroad in the 'War on Terror,'” International Review of the Red Cross, vol. 87, no. 857, March 2005, note 22, p. 45, and note 6, p. 41.
} 
take urgent measures necessary to have the legal status of the detainees at Guantanamo Bay determined by a competent tribunal.” The United States disputed the Commission's jurisdiction. The Commission rejected the United States’ objections and maintained its request. The matter was never resolved as the "Commission did not subsequently receive any information indicating that its request for precautionary measures had been complied with.” But despite the Inter-American Commission reiterating its concern about the Guantanamo detainees each year after its initial issuing of precautionary measures, there is little evidence that the United States changed its behavior or policies. The only solace for the IACHR came when the United States Supreme Court ruled similarly to it in 2005 and again in 2008, although to this date most detainees have still not been "produced" or had the charges against them publicly proclaimed by their jailers.

The habeas corpus petitions of several Guantanamo detainees were also filed in US courts. Initially, in Rasul v. Bush, 542 U.S. 466 (2004) the United States Supreme Court ruled that habeas corpus petitions could be filed by these detainees. Some lower courts affirmed and other courts denied their appeals. Congress then passed the Detainee Treatment Act of 2005 attempting to strip Guantanamo detainees of habeas corpus rights. In Hamdan v. Rumsfeld, 548 U.S. 557 (2006) the United States Supreme Court reaffirmed the importance of habeas corpus and ruled that the Detainee Treatment Act was not relevant to cases already pending before it. Congress then passed the Military Commissions Act of 2006 stripping habeas and other judicial appeals from all Guantanamo detainees regardless of whether their cases were pending before US courts or not. In Boumedienne v. Bush, 53 U.S. (2008), a deeply divided US Supreme Court ruled that the Military Commissions Act was unconstitutional because of its denial 
of the fundamental right of habeas corpus as an instrument of the protection of individual liberty and the rule of law.

What is most significant, as a matter of international law, is that the InterAmerican Commission did not feel it could take stronger measures against the United States in the Guantanamo case. Indeed, even after it became clear that the United States would ignore the Commission’s Precautionary Measures, the Commission did not seek further measures to protect the Guantanamo detainees, who the commission admitted were at grave risk. It is striking that there has never been a decision of the InterAmerican Commission of Human Rights against the United States on this issue or anything stronger from the Commission than the "request" that was articulated above. So, while it is true that the Inter-American Commission at least took up the issue of the deprivation of rights of the Guantanamo detainees, the result is quite far from minimally satisfactory - calling into question the ability of at least this particular regional human rights commission, if not the entire structure of human rights commissions, to protect procedural rights such as those of habeas corpus.

My view is that more is needed to enforce such procedural rights than is currently on offer. Part of the difficulty is that violations of procedural rights simply do not capture people's imagination the way that violations of substantive rights do. When the substantive crimes of genocide or ethnic cleansing occur, the "conscience” of the world's community is easily aroused. And so it matters less whether the protections offered are regional or global, although with the institution of the International Criminal Court, there is what promises to be an effective global enforcement mechanism for these substantive rights violations to go along with the regional bases of protection. 
So far, procedural rights have been protected, if at all, largely through regional human rights commissions and courts. The regional human rights commissions and courts are not part of the international criminal justice system but form their own separate system of international human rights law. But there are international institutions that operate globally, not merely regionally, and secure substantive rights. The Security Council is empowered to sanction States that would violate the global norm against aggression. The International Criminal Court provides sanctions for violations of the global norms against genocide, crimes against humanity, and war crimes. Piracy and slavery have been condemned in large multi-lateral treaties that are enforced by aut dedere aut judicare principles mandating that States either prosecute or extradite those responsible for such violations of global norms. ${ }^{39}$ Procedural rights need a similarly global protection institution.

What I envision could be simply understood as an international court of appeals from the regional courts and commissions of human rights. Or such a court could also, in a limited set of contexts, be an international court of first impression where one did not have to exhaust all other remedies before these regional courts. Or the court could also be a court handling appeals from decisions rendered by domestic or regional courts. Whatever is its form something like a Global Court of Equity is needed to deal with the procedural rights that must be protected for an international rule of law. The upshot would be that there would no longer be legal black holes where detainees could languish in prison for years without ever having charges against them publicly proclaimed.

\footnotetext{
${ }^{39}$ M. Cherif Bassiouni and Edward M. Wise, Aut Dedere Aut Judicare: The Duty to Prosecute or Extradite in International Law, Ardsley, NY: Transnational Publishers, 1995.
} 
Many who have written on the rule of law have not recognized the central role of habeas corpus. Lon Fuller only mentions habeas corpus once in his lengthy chapter on the rule of law in his book The Morality of Law, ${ }^{40}$ and Hart does not mention it at all. And even Fuller does not give to habeas corpus the sort of role in procedural due process that I have argued that it should have. But both Hart and Fuller certainly supply the theoretical basis for supporting habeas corpus rights, especially at the international level. The seemingly innocuous right that a prisoner be brought out of the dungeon and have the charges against him or her publicly proclaimed is indeed crucial for the protection of many other substantive rights, but it is also a value in itself insofar as it is a crucial component of the rule of law. And when thinking about the international rule of law, habeas corpus should be one of the first rights protected. Natural justice, as understood from Aristotle's time to the present, demands as much.

${ }^{40}$ Lon Fuller, The Morality of Law, New Haven, CT: Yale University Press, 1964, p. 81. 